\title{
An Interpretation of the Natural Scenes in Sons and Lovers
}

\author{
Hongzhi Wu \\ Qingdao University of Science and Technology, China
}

\begin{abstract}
With the arrival of the $20^{\text {th }}$ century, the industrial civilization enters a critical stage in its development. The blind chase of material wealth has resulted in more and more social problems. Furthermore, when Christian faith was wiped out along with the pastoral living style, a spiritual wasteland is resulted. Desperation becomes an incurable modern disease. As a responsible novelist, Lawrence attempts to find a cure to this modern disease. This paper explores the social, religious and emotional implications of the depictions of natural scenes in Sons and Lovers, and concludes that nature appears in this novel as a salvation force against the industrial distortion of human nature.
\end{abstract}

Index Terms - nature, industrialism, distortion, religion, sexual relations

\section{INTRODUCTION}

D. H. Lawrence lived in a time when the British society was experiencing a great change. Britain as the first imperial capitalist nation was beginning to lose its leadership in the world politics and economics. Its glory as the world factory seemed to have been withering all the time. As a result, British people's attitude towards life and the industrial civilization underwent a transition as well. The enormous wealth produced by the industrial civilization gradually lost its false glory, while more and more social problems of the industrial society began to plague the public nerve, such as the income gap, poor working conditions, the collapse of the Christian faith, the deterioration of the overall moral standard, and the environmental pollution, etc. In fact, negative reviews about the destructive impact of the industrial civilization on the moral foundation of the British society began long before Lawrence's age. In the works of many of the late 19th century realist novelists, the industrial civilization was given a very gloomy portrait, such as in the works of Charles Dickens, Hardy and Eliot. And such passion against the industrial civilization is densely located in Lawrence's works.

Here the wasteland spirit coined by T.S. Eliot in his modern epic "Waste Land" has to be mentioned in order to illustrate the damage on human soul caused by industrial civilization. As a civilization built on cruel exploitation of the workers' surplus value, and on cold-hearted robbery of natural resources, its development will definitely leads to regional conflicts, and ultimately to world wars. This is a theory proved by the two world wars, as a result of which the already greatly weaken Christian belief has been completely devastated, causing a vacuum in faith and a horrible wasteland in 20th century social mind. In order to restore faith in god, or to help people tolerate the postwar trauma, many literature man use their pen as a weapon to rebel against the social evils caused by the industrial civilization.

Lawrence is a very successful figure spending most of his effort in their respect, trying to help the world to regain their heavenly bestowed virtues and their good old faith. Different from the 19th century realist novelists, who focus more on the economic exploitations suffered by the workers, Lawrence cares more about the destructive influence of the industrial civilization upon human relations, upon the spiritual well-being of individuals. While his forefathers insist on nature's joint effect in causing the misery of industrial life, Lawrence regards nature as a victim of the industrial invasion as well. What's more, he regards nature as a force reacting against such invasions. And in his opinion, nature seems to represent the source of salvation. By returning to nature, and rediscover the divinity of nature, people will ultimately release their own bound nature, thus regain their spiritual integrity and sense of peace. Here Sons and Lovers is chosen as a typical example of how Lawrence makes his point about the importance of nature to the spiritual integrity of 20th century people. As his first successful novel, Sons and Lovers illustrates how the industrial civilization castrates the hero's family, making them incapable of love. Being contaminated by the industrialized value, members of this family along with their neighbors unknowingly apply a distorted love concept on their beloved ones; thus rather than help them prosper, they suffocate their dream, their love, and their life. The father yields to the conventional patriarchal role forced on him, and gradually lose his natural sense of humor. Deprived of the husband's love, the mother is forced to center all her love and hope on her sons, and eventually suffocates their life. Thus a tragic sense pervades the entire story. Only when nature steps in, will the light of hope temporarily pierce through the thick industrial clouds to alleviate the pain and sorrows of the characters, and help their soul wake up a while from their sound sleep.

Therefore, more than a mere passive background, nature in Sons and Lovers is a participant of the plot, sometimes even a mentor for human soul, and it is very human like. According to Lawrence, nature refers to the scene consisted by the farm, the crops, the woods and flowers, the rivers, the sun, the moon and the stars. In contrast to the dull, distorting, and ugly industrial society, nature represents the lively, harmonious and beautiful agricultural society before the 
industrial civilization. Though some critics argue that Lawrence is a modernist writer and it is impossible for him to be sickly nostalgic, one can't deny his favor of the natural scene and the agricultural lifestyle which is more than closely related to nature than the industrial lifestyle. His favorable view of the country life is clearly presented in the opening scene where the background setting of the story is introduced. In this introduction he shows his disgust toward the industrial civilization obviously. Because of the industrial development, the beautiful countryside view has been destroyed. "Corns and meadows" are destroyed to make place for coalmines; people's labor has lost its dignity, and men work "like ants into the earth" (Lawrence, 1979, P7). As a product of the industrial civilization, the coalmines are like black studs, nailing "on the countryside" (Lawrence, 1979, P8) — or the healthy body of earth. The arrangement of the houses for the coilers indicates the industrial civilization has no regard for the beauty of nature, because despite of the pretty trees and flowers in the front garden, the living space--the kitchen where people spend most of their time is placed at the back part facing the ugly ash-pits. Anyone familiar with the Christian culture may agree that ash reminds one of death, while pits remind one of hell. Therefore, through the layout of the house's different functional zones, Lawrence implies that the industrial civilization is plagued with death, and has come to the edge of its fall.

\section{Detailed ANALYSIS OF THE NATURAL DEPICTIONS}

The following is a more detailed analysis of the implications of natural depictions in the novel, which come in four aspects: nature and beauty, nature and religion, nature in contrast to industry, nature and sexual relation.

\section{Beauty of Nature}

Lawrence often uses very poetic language to portrait natural scenes and objects, and nature in his works seems to be the incarnation of beauty itself. Such beauty is very essential for people drowned by the industrial world. The beauty of nature becomes a source of power and it enables people to forget their physical miseries and reach a transcendental land of hope. The industrial production prevents workers from obtaining pleasure from their labor by making their work more and more dull and mechanic. The work in the mine extracts every bit of energy out of the coilers, and what's more, such work dulls the mind of the coilers. As a result, mutual communication cannot happen in the family, and this is just the case for the Morel family. Mr. Morel is always too tired and frustrated to appreciate his wife's taste in tidying the house; Mrs. Morel's pride and knowledge prevents her from understanding her husband's insensitivity. The family harmony is destroyed and hot and cold wars begin to take its place. And that's what happens in the Morel family. In the first chapter, after their fight, Mrs. Morel is locked out of the house. Once she is in the front yard, she comes to contact directly with nature and begins to draw power from it. Firstly, it's the moonlight that helps her to regain soberness by cooling "her inflamed soul". With the soberness, she begins to review her fight with her husband and feels something biting in her conscience. Secondly, she comes to a stage of sudden awareness. She begins to observe the white lilies in the moonlight.

The tall white lilies were reeling in the moonlight, and the air was charged with their perfume, as with a presence. Mrs. Morel gasped slightly in fear. She touched the big, pallid flowers on their petals, and then shivered. They seemed to be stretching in the moonlight. She put her hand into one white bin: the gold scarcely showed on her fingers by moonlight. She bent down to look at the binful of yellow pollen; but it only appeared dusky. The she drank a deep draught of the scent. It almost made her dizzy. (Lawrence, 1979, P35)

First of all, the above part of is a scene of natural beauty. The moonlight light is crystal clear, and all embracing; the lilies seem to be stretching because the air is filled with their fragrance. The moonlight, the perfumed air, and the lilies combine into a very strong power, and everything in its embrace slowly gets assimilated in it. Once assimilated into the nature, a person's own nature is turned on and he or she undergoes a process of purification. One's mind seems to be transcended to the sky level, and all the pains, sufferings of the human world cannot touch him or her. Besides the spiritual peace, the person's physical body also gets a profound rest under such circumstances. As is known, Lawrence thinks the satisfaction of sexual desire is very important for a happy life. The same message can be found in this contact between human and nature. The lily flower is often considered as a symbol of the female sexual organ, and Mrs. Morel's dipping into the flower cup is like the sexual intercourse. And the fact that Mrs. Morel feels dizzy and completely loses the sense of her body is an obvious reference to the ideal sexual orgasm, in which the two persons becomes one and there's nothing left except pure happiness.

The beauty of nature has such a powerful effect on things, that they become as beautiful as nature itself. All evils are purified, and man becomes all kind and understanding. And this is what happens to Mrs. Morel. Once she is in the moonlight, she becomes cool and begins to have her own fault examined and purified. Nature as a power of beauty is always outside there. What one needs is to step out of one's concrete enclosure and to appreciate such beauty. When Mrs. Morel does this, "the small frets vanish, and the beauty of things stands out, and she had the peace and the strength to see herself." (Lawrence, 1979, P50)

Some critics think that the "lily flower" in this scene indicates the death of love between the husband and wife, and it also foreshadows the death of William. And William's tragic engagement to the London girl, whose name happens to be Lily, seems to prove this idea. (Xu Jingzhen, 2005) In fact, there is still doubt of the truthfulness of such ideas. The love between husband and wife seems to have died long before the fighting scene. Instead of causing the death of a love, the lily flowers save the wife from breaking her heart over an already dead love. As to Williams' girl friend, she could not be simply understood as a true presentation of the Lily flower. On the contrary, she is a presentation of the flower 
twisted by the industrial civilization. She has been raised in London, the center of the industrial civilization, so it is natural for her to be infected by some of the industrial plagues, such as vanity, shallow-mindedness, carelessness in spending money, etc. And these weaknesses in her characters can be attributed to the holy flower of lily. Suppose she lived in the countryside, she could have been as hard working and independent as Clara, or as faithful as Miriam.

\section{Religious Sense in Nature}

The Christian implication is another important aspect of the nature depiction in Sons and Lovers. After the birth of Paul, one day Mrs. Morel took the baby to the top of the hill. The meadows and the evening lights begin to influence her again.

The sun was going down. Every open evening, the hills of Derbyshire were blazed over with red sunset. Mrs. Morel watched the sun sink from the glistening sky, leaving a soft flower-blue overhead, while the western space went red, as if all the fire had swum down there, leaving the bell cast flawless blue. The mountain-ash berries across the field stood fierily out from the dark leaves, for a moment. A few shocks of corn in a corner of the fallow stood up as if alive; she imagined them bowing; perhaps her son would be Joseph. (Lawrence, 1979, P49)

According to the Christian belief, the world is created by God. And the sun, the moon, the earth, the sea and all the living things all are the creations of God, and they act as manifestations of the almighty of God. So when a Christian comes to appreciate nature, he or she feels the power of God. In this condition, Mrs. Morel feels she is very closely connected with god. And she becomes boasted about her son. In her imagination, he is going to a Joseph, the savior of the world, and the world is going to bow before him. So she calls him "my lamb", which is a term used to refer Jesus Christ. Under the stare of the baby savior, she feels the guilt in her and her husband. "And a wave of hot love went over her to the infant." This scene is a very powerful display of the salvation strength lying in the Christian tradition. And nature acts as the media through which people could get in touch with this salvation power. Through this media, we come to realize what is wrong with the modern society, that the industrial civilization is a civilization without love.

\section{Industrial Scene against Nature}

In contrast to the benevolent nature, the industrial scenes in Lawrence's depiction are often full of darkness, horror and death. A case in point is the depiction of Paul's first impression of Mr. Jordan's factory.

Suddenly they spied a big, dark archway, in which were names of various firms, Thomas Jordan among them.

And they ventured under the archway, as into the jaws of the dragon. They emerged into a wide yard, like a well, with buildings all round. It was littered with straw and boxes, and cardboard. The sunshine actually caught one crate whose straw was streaming on to the yard like gold. But elsewhere the place was like a pit. (Lawrence, 1979, P118)

This dwelling conveys nothing pleasant; instead, it resembles a prison in many ways. And the dragon mouth image symbolizes the all-swallowing nature of the industrial system. Once a person is in the system, he is going to lose his or her own nature. In another word, the evil creature kills his nature. The well image is a strong symbol of entrapment, and here freedom becomes a luxury. The beauty of nature is closed to the insiders, and litters become their only company. The allusion to the pit in the final sentence is a definite reference to the universally hell-like conditions of the working environment. Here the image of the golden sunlight beaming down the hole among the buildings overhead reminds people of the light of heaven. It summons people to break the industrial enclosures and return to nature.

\section{Nature as a Sexual Language}

Since nature is full of different images and objects, almost all people could find expressions for his or her own emotions in the natural world. And this is especially true in Sons and Lovers. In Paul's first love, his girl, Miriam, tries to keep their relation completely spiritual. But for Paul, the physical impulse is grow stronger and stronger within him, and the suppression of it becomes a torture to him. One day, when Paul and Miriam sat together at the sunset, Paul pointed at the pine-trunks embraced in the sunlight and said: "I wanted that. ... There's God's burning bush for you, that burned not away." (Lawrence, 1979, P189) God's burning bush is an explicit allusion to the story of "Moses" in the Bible. When Moses is alone in the field one day, God reveal himself in the form of burning bush. And he tells Moses to go to Egypt, and save the enslaved Jewish people, and lead them out to Jerusalem. In the theory of Dr. Freud, any stick-shaped object may stand for male sexual organ in people's subconscious. Combined into one concrete message, the pine-trunks painted red by the sun stand for Paul's burning desire to have intimate body contact with Miriam and it's also a sign from God for them to fulfill that desire. So in his eyes, the lighted pine-trunks become the burning bush, which is used by God to deliver a message to Moses. By directing Miriam's attention to these trunks and by calling them God's burning bush, Paul is trying to reveal his sexual desire to Miriam. And he wants Miriam to feel that impulse too, and to answer the call of God just like Moses.

For Miriam, nature is also full of meaning. However, she only sees the holy side of it. The white rosebush in the dark woods tells us the image of nature in her eyes. "Point after point the steady roses shone out of them, seeming to kindle something in their souls. The dusk came like smoke around, and still did not put out the roses." (Lawrence, 1979, P198) And with the white roses, she intends to quench the sexual desire in Paul. Judging from this example, nature is like a symbolic language, which can be used by everyone to find an outlet for his or her particular emotions. Yet Lawrence seems to value Paul's interpretation of nature higher than that of Miriam. Because like his mother, Paul is able to let go of his nature, while Miriam always worships nature. She is looking up to nature from the place of a pilgrim. That is to say, nature, though admired in her eyes, could never find echo in her heart. And that's probably why she always tries to avoid sex with Paul. Her desire for Paul's body is always under suppression, and it's a part of her character that has 
been distorted by the puritan doctrines.

Different from his relation with Miriam, Paul's relation with Clara is expected to be a healthier one. They both have desires for sensual pleasure and they don't deny that desire. Such mutual attraction joins them together. Nature also plays an important part in their relation. And this is especially true in their first love adventure in the riverside bushes after the rain. The day is wet because of the rain, and it is fit for the growth of things, including love. When they walk on the bank, the things that they see encourage their inner desires.

The cliff of red earth sloped swiftly down, through trees and bushes, to the river that glimmered and was dark between the foliage. The far-below water-meadows were very green. He and she stood leaning against one another, silent, afraid, their bodies touching all along. There came a quick gurgle from the river below. (Lawrence, 1979, P376)

Everything is washed by the rain, and radiates vitality into the surroundings. The earth becomes freshly red, and the meadow becomes very green. All the things seem to encourage them to take action to fulfill their desire. Leaning against each other, the desire inside their bodies make great noise as loud as the roaring river torrent behind the bushes. And their later descending to the river for a place of privacy is a clearly indication of their intention to answer their bodies' sexual nature's call. If they truly opens themselves to each other and take each other in themselves, this relation is bound to succeed. However, it fails again. And this time the fault lies in Paul. His special attachment to his mother makes him unable to accept another woman into his life, so when he makes love with Clara, it is not Clara that he sees, but an abstract woman. In this way, their love is not a natural love, but is twisted. It's the pursuit of pure sensual pleasure that connect them, and there is no spiritual communication at all. Their relation is like the twisted relation between individuals in the industrial society, where people's life is centered on money and material pleasure, so the love appears and disappears along with the material profit. Man is a creature with a soul according to the Christian belief, and the love without soul communication is no different from the activity of animals, and it is against human nature. Therefore Paul's relation with Clara is doomed to fail. And the same case is with the love between William and Lily.

\section{CONCLUSION}

From the above analysis, it is clearly noted that nature in the imaginary world of Lawrence could be very abundant in meaning. First of all, it is a perfect example of beauty and spiritual salvation. When contrasted with the ugliness presented by industrial constructions, nature as a mirror clearly reflects not only the physical damage cast on our living world by industrial production, but also exposes the distorted human relation in the industrial world. Hereby, the fragile nature is wielded by Lawrence as a powerful sword against the inhumanity of Puritanism and industrialism. In another sense, nature is also full of sensual and religious connotations, and it is used to signify the progress and frustrations in the development of human relations. By digging into these depictions of natural depictions, the readers can have a more explicit insight into the surging emotions and desires in the characters' mind. Finally, nature is far more than a mere passive witness of human activity. Instead, it has always been and still is an active participant of all human life. It is the beginning point of human life, and also the ending point of all human beings. When human society moves into the industrial age, we tend to pull further and further away from the natural world in which process we are becoming less and less human. We don't know how to love and protect our mother nature, and then we become cold and cruel to our fellow human beings. By pointing out the divinity in nature, Lawrence may not exactly calls for the returning to an idyllic life, but he surely is asking for a recovering sense of nature's beauty and a closer attention to it, in hope of restoring the declining moral standard and fraternity ideal between man and man.

\section{REFERENCES}

[1] Dennis Jackson and Fleda Brown Jacson. (1988). Critical Essays on D. H. Lawrence. G.H.H: Massachusetts.

[2] D. H. Lawrence. (1979). Sons and Lovers. UK: Penguin Books Ltd., 7, 8, 35, 49, 50, 118, 189, 198, 376.

[3] Gamini Salgado. D. H. Lawrence. (1969). Sons and Lovers. Houndmills: Macmillan.

[4] Martin Krampen and Klaus Oehler. (1987). Classics of Semiotics. New York: Plenum Publications.

[5] Neil Champion. D. H. Lawrence. (1989). Life \& Works. Hove: Wayland Publications.

[6] Nigel Messenger. (1989). How to Study a D. H. Lawrence Novel. New York: Macmillan Publications.

[7] Robert Scholes. (1982). Semiotics and Interpretation. Haven: Yale University Press.

[8] Terry Eagleton. (1983). Literary Theory: An introduction. Oxford: Basil Blackwe11.

[9] Xu Jingzhen. (2005). An Interpretation of the Flower Symbols in 'Sons and Lovers'. The Academic Journal of Beijing International Studies University (2), 55-57.

Hongzhi Wu was born in Hu'nan, China in 1975. He received his Master's degree in Linguistics and Applied Linguistics from University of Electronic Science and Technology, China in 2005.

$\mathrm{He}$ is currently an associate professor in the School of Foreign Languages, Qingdao University of Science and Technology, Qingdao, China. His research interests include Language Test, Statistics, Scientific English and Intercultural Communication.

Dr. Wu is a member of the Chinese Association of Modern Education. 